https://doi.org/10.22364/hssl.29.1.04

\title{
THE ROLE OF EXPENDITURE ON RESEARCH AND DEVELOPMENT (R\&D) IN PROMOTING ECONOMIC GROWTH AND COMPETITIVENESS
}

\section{Sandra Jekabsone ${ }^{1}$}

Faculty of Business, Management and Economics, University of Latvia, Riga, Latvia

\section{Ilze Sproǵe}

Faculty of Business, Management and Economics, University of Latvia, Riga, Latvia

\section{Solvita Kristone}

Faculty of Business, Management and Economics, University of Latvia, Riga, Latvia

\begin{abstract}
Development of science and research is fundamental for economic growth, as well as the competitiveness of a country. Taking into account the potential decrease of EU funds financing and the limited amount of Latvian national financing, it is necessary to ensure that the efficiency of the use of financing is maintained and raised further. The aim of the study is to evaluate the impact of the EU funds funding activities of 2007-2013 and 2014-2020 on science, research and innovation support activities of Latvian research institutions, as well as the sustainability of the results obtained within the support activities, taking into account the measures planned to support research, development and innovation during the programming period of EU funds 2021-2027.

The results of the research show that expenditure in research and development $(R \& D)$ in Latvia is small and dependent on European Structural Funds (currently R\&D investments are mainly attracted by EU funds), which is not a sustainable solution for $\mathrm{R} \& \mathrm{D}$ development, considering that this financing and its availability are periodic and in the future. This requires consistent long-term public and private (business) $\mathrm{R} \& \mathrm{D}$ investment.
\end{abstract}

Keywords: Latvian scientific institutions (SI), research and development (R\&D), innovation, competitiveness.

1 Contact: Sandra Jekabsone; sandra.jekabsone@lu.lv; Faculty of Business, Management and Economics, University of Latvia, Riga, LV-1050, Latvia. 


\section{Introduction}

Developments in science, technology and innovation are major drivers of change in modern societies. R\&D is one category of spending that develops and drives new technologies. From the perspective of competitiveness, private sector firms are prone to focus their $R \& D$ on "applied" projects and many government-sponsored technological advances have been instrumental in driving economic growth and rising living standards (Priede, 2013). Unfortunately the dynamics of competitiveness indicators show that the model of the Latvian economy has not changed and the benefits of low cost competitive advantage still remains. In order to ensure the development of the Latvian science system, to improve the quality and competitiveness of science, as well as to plan investments within the EU funds programming period 2021-2027, it is important to evaluate the efficiency of investments made so far in certain Latvian scientific institutions.

The aim of the study is to evaluate the impact of the EU funds funding activities of 2007-2013 and 2014-2020 on science, research and innovation support activities of Latvian research institutions, as well as the sustainability of the results obtained within the support activities, taking into account the measures planned to support research, development and innovation during the programming period of EU funds 2021-2027.

To achieve the aim of the research the following tasks were determined:

1) to look at the amount of EU funding in the last two programming periods to support science, research and innovation;

2) to evaluate its impact on the functioning of Latvian scientific institutions (HEI); 3) to look at the sustainability of the results obtained within the support activities.

The article analyses the impact of ten EU-funded activities on the key characteristics of the Latvian science and innovation system - human resources, collaborative networks, internationalisation of science, collaboration with business, research infrastructure, quality of research and its effectiveness.

Scientific methods used in the research: analysis of scientific literature, empirical analysis, grouping, comparison and decomposition of data.

Theoretical and methodological basis of the study is specialised economic literature and foreign scientific research papers, including studies by economists of IMF, OECD and European Commission, Legislation of the Republic of Latvia, as well as EUROSTAT and CSB statistical data. 


\section{Theoretical background}

Economic growth, productivity and its causal relationships have for years served as a basis for discussion among economists. Many authors emphasise importance of research and innovation in economics growth (for example, Lopez-Rodriguez \& Martinez-Lopez, 2017 etc.). Today's understanding of the key drivers of economic growth dates back to at least 1911, when Schumpeter argued that economic growth depends on innovation through competition between firms (Schumpeter, 1982). Innovation and the subsequent technological progress in economic growth models have become increasingly important over time. In the neoclassical or Solov model of economic growth, showed that economic growth in the long run depends on the development of technologies that allow more efficient use of labour and capital, increasing their productivity (Solov, 1956). Unfortunately, in Solov model, it does not provide an explanation for technological progress, prompting many economists to ask additional questions. Lucas, Romers and others complemented the neoclassical model with investment in $R \& D(R \& D)$, in other words, the accumulation of knowledge and human capital as a determinant of technological progress, helping to better understand observed differences in growth between countries (Romers, 1990).

According to one of the most significant research work in their field (Koe and Helpman, 1995), there are several channels through which $R \& D$ investment increases labour productivity. Firstly, by enabling the creation of new products and services by making more effective use of existing capital. Second, it makes it easier to adopt more advanced technologies used in other countries, thus improving the quality of capital. Thirdly, through direct learning and self-development of new technologies and indirectly through the import of products and services using the latest technologies. Similarly, Griffith notes that investment in R\&D has two roles - to promote new innovation and to encourage imitation of other innovations (Griffith, 2002). Imitation is important to promote the so-called income convergence process in countries that are not innovation leaders and ranked lower in the world in terms of income. By actively investing in $R \& D$, one gains knowledge that can be used to understand and apply breakthroughs and advanced technologies. In addition, the farther away a country is from the forefront of innovation, the higher the productivity growth through R\&D investment. Conversely, as a country moves closer to the advanced economies, the return on each euro invested in $R \& D$ is gradually decreasing (the effect of falling marginal yield). 


\section{Research results and discussion}

Productivity growth has fallen over the past two decades, especially since the 2008 global financial crisis. This trend, combined with low or declining multi-factor productivity growth in several countries and sectors, has raised concerns about the ability of research and innovation activities to support economic growth and social wellbeing. Scholars continue to debate the reasons for the slowdown. Some point to slower rates of innovation, which is the root of productivity. Others point to the historical time lag between innovation and its impacts on productivity (OECD, 2018).

In such a situation ensuring economic growth in the world, including Latvia, is even more acute. Challenges related to stimulating productivity, mainly through:

- human capital and technological progress,

- making more effective use of the opportunities offered, and

- investment in research and development.

This applies equally to the private and public sectors. One needs to create a coordinated (including a strong internal one) monitoring systems of strategic public assets, in particular non - financial assets coherence and complementarity of objectives; a more efficient business environment and wider public good.

A key challenge in boosting productivity will be the ability of a country to find effective solutions (on resource management and systematisation) with respect to the subsequent national information system integration, by making e-services more widely available, not only making them more user-friendly, but also allowing a significant proportion of public sector employment to be redirected to other economies industries.

The Commission for Sustainable Development, agreed in 2014 on the issue and in-depth research in four thematic directions were identified as the main bottlenecks in Latvia in the context of economic competitiveness:

- offsetting the quantitative decline in the number of people by the quality of human resources increase;

- closer links between science and business;

- creating a fair business environment; and

- efficient and sustainable use of natural resources and public assets. Investment in Research and Development (R\&D) fosters new innovation and fosters the innovation of others, thereby increasing overall productivity. By actively investing in $R \& D$, one gains knowledge that can be used to understand and apply breakthroughs and advanced technologies. Investing in $R \& D$ thus contributes to the growth of knowledge, which contributes to competitiveness and added value. In addition, the farther away a country is from the forefront of innovation, the higher the productivity 
growth through $R \& D$ investment. Latvia is in the penultimate position among the EU countries in terms of R\&D financing against GDP. Low R\&D investment may have a negative impact on Latvia's long-term growth, limiting opportunities to develop knowledge and technology-intensive industries and achieve higher productivity (see Figure 1).

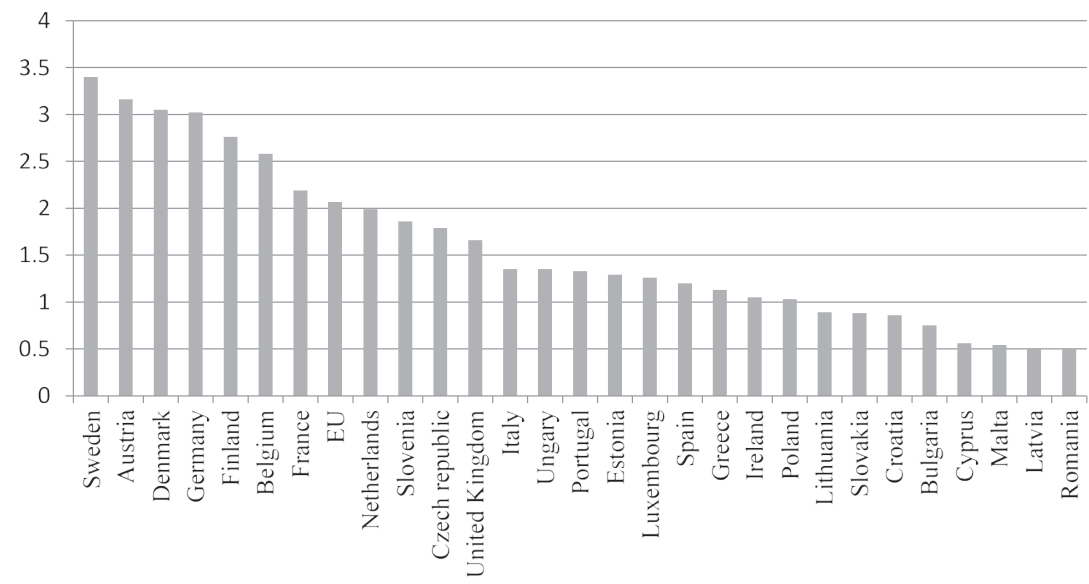

Figure 1. R\&D expenditure (\% n GDP) in EU Member States in 2018

Source: Author's conclusions are based on CSB databases

Latvia's total R\&D expenditure in 2018 was 186.2 million EUR (CSB database, 2020). Research organisations account for almost $50 \%$ of total investment, while entrepreneurs make up just under 25\% (46.3 million EUR). In other OECD countries, firms have resumed their R\&D investment since the financial crisis, fuelled by restored profitability and the increasingly generous R\&D fiscal incentives offered by many governments (OECD, 2018). Enterprises in Latvia, compared to those in other EU Member States, are characterised by their lack of innovation perspective, small size, low added value/complexity, high resource intensity and lack of integration into global value chains (Szydłowsk, 2019).

Expenditure in $R \& D$ in Latvia is small and dependent on European Structural Funds (currently R\&D investments are mainly attracted by EU funds), which is not a sustainable solution for $R \& D$ development, considering that this financing and its availability are periodic and in the future. This requires consistent long-term public and private (business) $R \& D$ investment. Without further substantial increases in $R \& D$ investment, it will not be possible to provide the economic knowledge needed for 
faster growth, human resources, technological development progress and business incentives to invest in R\&D and innovation. Government support is essential to promote basic research, and to provide incentives and appropriate conditions for effective science-industry relationships. In addition, it is crucial that public investment in $R \& D$ is channelled through public budgets and not just EU funds. Latvia is one of the largest recipients of EU funds in relation to its GDP and relies heavily on the EU budget to finance public investment and policies support to innovation and skills development (Szydłowsk, 2019).

In more detail, the main source of $R \& D$ funding in 2018 was European Commission funding (65.5 million EUR, or 35\% of total R\&D expenditure). Most of the EU funds are spent on $R \& D$ in universities and research institutions. The second most important source of funding in 2018 was the research base and development funding from the state budget (32.9 million EUR, or $18 \%$ of total R\&D expenditure). The third source of higher R\&D expenditure was self-financing by companies (30.9 million EUR, or $17 \%$ of total $R \& D$ expenditure)

An important insight into the development of the R\&D system is also provided by the analysis of the results between of different investment programs. It allows for an in-depth analysis of $R \& D$ performance within each RIS3 area, as well as identifying sector specificities and different needs for developing $R \& D$ capacity in each area (see Figure 2).

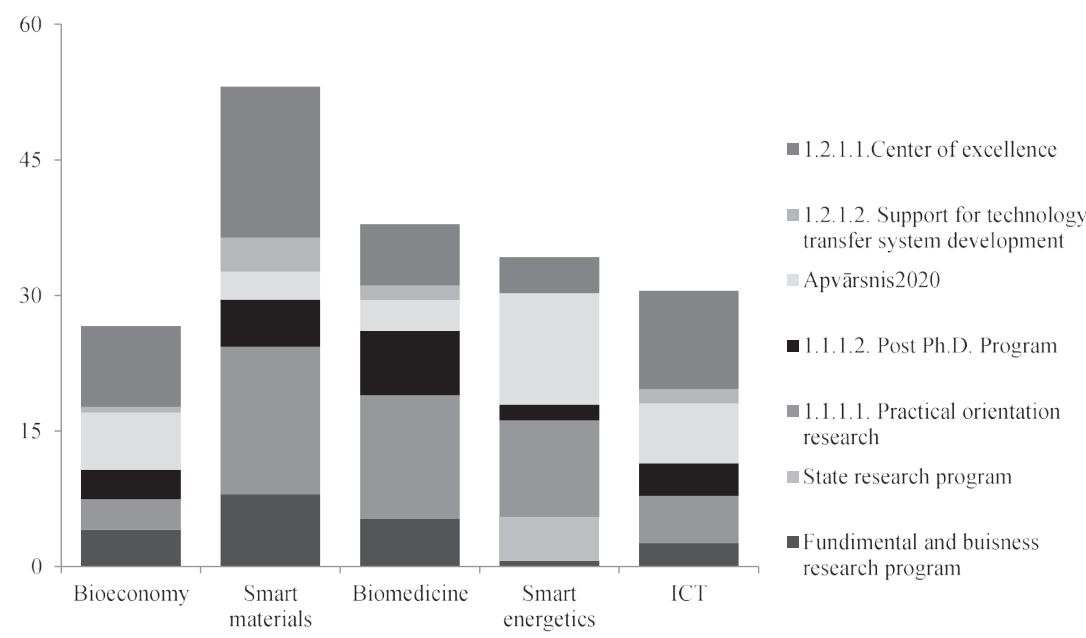

Figure 2. Financing R\&D broken down by source in Latvia 2014-2018 (million EUR) Source: Author's conclusions are based on EUROSTAT databases 
Overall, as shown in Figure 2, most financial resources are invested in smart materials. In turn, for the development of smart energetics spent on all national research programs as well as most of the Horizon 2020 funds.

\section{Conclusions, proposals, recommendations}

The 2014-2020 financial instruments, while generally contributing to the development of research and innovation capacity of scientific institutions and enterprises, have not provided a sufficiently integrated approach to linking research and technological development and, consequently, developing innovation capacity.

The current high dependence on structural funds may not be sustainable in the longer term, so Latvia should seek a better balance between national and European funding.

The new period should be shaped by defining more capacious and mutually integrated instruments, as well as more specific objectives and clear and measurable indicators of the results to be achieved. Identified thematic sub-areas in $R \& D$ projects should be taken into account in the planning and definition of strategic ecosystems.

In the design of programs, it is necessary to work on the reduction of the administrative burden where activities aimed at reducing the administrative burden on researchers and higher education projects cofinanced by EU funds are already underway.

There is also an identified need for better knowledge transfer, which would imply the need to develop targeted university-based knowledge transfer activities with a view to establishing functional platforms for transferring knowledge and technology to the public, including entrepreneurs (implementation of extension services).

\section{REFERENCES}

Central Statistical Bureau (CSB) of Latvia. (2020). Statistic Database. [Online] Available at: https://www.csb.gov.lv/lv/statistika/db [Accessed 20.102.2020].

Cross-Sectoral Coordination Centre. (2012). National Development Plan. Available: http:// www.pkc.gov.lv/sites/default/files/inline-files/NDP2020\%20English\%20Final 1. pdf. [Accessed 16.11.2019].

David Coe, Elhanan Helpman. (1995). International R\&D spillovers. European Economic Review. 39 (5), pp. 859-887.

Eiropas Komisija. Komisijas dienestu darba dokuments 2019. gada zinojums par Latviju. [Online] Available at: https://ec.europa.eu/info/sites/info/files/file_import/ 2019-european-semester-country-report-latvia_lv.pdf [Accessed 16.11.2019].

Eiropas Komisija. Pētniecība un inovācija [Online] Available at: https:/europa.eu/ european-union/sites/europaeu/files/research_lv.pdf [Accessed 16.11.2019]. 
European Commission. (2010). Europe 2020 strategy. Available at: https://ec.europa. eu/info/business-economy-euro/economic-and-fiscal-policy-coordination/eueconomic-governance-monitoring-prevention-correction/european-semester/ framework/europe-2020-strategy_en. [Accessed 16.11.2019].

Eurostat (2020). Statistic Database. [Online] Available at: http://ec.europa.eu/eurostat/ data/database [Accessed 20.102.2020].

Griffith, R., Redding, S. and Reenen, J. (2004). Mapping the Two Faces of R\&D: Productivity Growth in a Panel of OECD Industries. Review of Economics and Statistics. 86 (4), pp. 883-895.

Jesiḷevska, S., Šḳiltere, D. Inovācijas Latvijā. Realitāte un izaicinājumi. [Online] Available at: http://www.lza.lv/LZA_VestisA/72_4/5_Svetlana\%20Jesilevska_Daina_Skiltere. pdf [Accessed 16.11.2019].

Latvijas nacionālā reformu programma "Eiropa 2020" stratēğijas īstenošanai. Progresa ziṇojums 2019 [Online] Available at: https:/ec.europa.eu/info/sites/info/ files/2019-european-semester-national-reform-programme-latvia-lv.pdf [Accessed 16.11.2019].

OECD Science, Technology and Innovation Outlook 2018 (2018), OECD Publishing, Paris.

Priede, J., Pereira, E. (2013). Innovation as a key factor in the international competitiveness of the European Union, European Integration Studies. 2013 (No. 7), pp. 212-221.

Romer, Paul M. (1990). Endogenous Technological Change. Journal of Political Economy. 98 (2), pp. S71-S102.

Schumpeter, Joseph A. (1982). The Theory of Economic Development: An Inquiry into Profits, Capital, Credit, Interest, and the Business Cycle. $10^{\text {th }}$ ed. London: Transaction Publishers. p. 224.

Solow, Robert M. (1956). A Contribution to the Theory of Economic Growth. The Quarterly Journal of Economics. 70 (1), pp. 65-94.

Szydłowsk, K., Zeps, V., Reklaitis, Z. (2019). Proposal of revenue sharing operational model and its implementation into the innovation ecosystem of Latvia which could be implemented within the framework of 2021-2027 Planning period, September 1, 2019, Available at: https://em.gov.lv/files/attachments/Revenue\%20 sharing\%20operational\%20model\%20\%20Latvia_Deliverable\%20FINAL_2509_ Deliverable.pdf [Accessed 20.02.2020]. 